\title{
Ideal temperature and storage period for commercial potato cultivars selected for frying
}

\author{
Renata Ranielly Pedroza Cruz ${ }^{1^{*}}$ (i) Ariana Mota Pereira ${ }^{1}$ (i) Wellington Souto Ribeiro ${ }^{2}$ (i) \\ Ana Izabella Freire ${ }^{1}$ (D) Franciscleudo Bezerra da Costa $^{2}$ (D) José Cola Zanuncio ${ }^{3}$ (D) \\ Fernando Luiz Finger $^{1}(\mathbb{D}$
}

'Departamento de Agronomia, Universidade Federal de Viçosa (UFV), 36570-900, Viçosa, MG, Brasil. E-mail: renataranielly426@gmail.com. ${ }^{*}$ Corresponding author.

${ }^{2}$ Departamento de Horticultura Tropical, Universidade Federal de Campina Grande (UFCG), Campina Grande, PB, Brasil. ${ }^{3}$ Departamento de Entomologia, BIOAGRO, Universidade Federal de Viçosa (UFV), Viçosa, MG, Brasil.

ABSTRACT: Potatoes for industrial processing must have high dry matter, low sugar and free from damage or disease. The objective was to determine the ideal temperature and storage period of commercial cultivars for frying. Tubers of Asterix and Cronos cultivars were stored in a cold chamber (Gallant CMC4 Premium) inside plastic boxes at 6 and $8{ }^{\circ} \mathrm{C}$ with 85 to $95 \%$ humidity for 180 days. Accumulated mass loss (PMA), alcohol insoluble solids (SIA), total soluble sugars (AST), non-reducing sugars (ANR), reducing sugars (AR), polyphenoloxidase activity (PPO) and enzymatic and non-enzymatic browning were analyzed. The PMA of Asterix at 6 and $8{ }^{\circ} \mathrm{C}$ and Cronos at $6^{\circ} \mathrm{C}$ was higher. The SIA of both cultivars stored at $6{ }^{\circ} \mathrm{C}$ were lower and AST, AR and ANR higher. Those parameters of Cronos and Asterix did not differ between temperature or storage period. The browning was greater in the fried sticks of Asterix and Cronos stored at $6{ }^{\circ} \mathrm{C}(4$ to 5$)$ for 60 and 90 days and at $8^{\circ} \mathrm{C}$ (2 to 3) for 180 days, respectively. The ideal temperature and storage period for Asterix and Cronos cultivars is $8{ }^{\circ} \mathrm{C}$ for a maximum of 120 days due to non-enzymatic browning.

Key words: conservation, french fries, low temperatures, Solanum tuberosum.

Temperatura e período de armazenamento ideais para cultivares comerciais de batata selecionadas para fritura

RESUMO: As batatas destinadas ao processamento industrial devem ter alto teor de matéria seca, baixo teor de açúcar e estar livre de danos ou doenças. O objetivo foi determinar a temperatura e o periodo de armazenamento ideais para cultivares comerciais para fritura. Os tubérculos das cultivares Asterix e Cronos foram armazenados em caixas de plástico a 6 e $8{ }^{\circ} \mathrm{C}$ com umidade de 85 a $95 \%$ por 180 dias. As perdas de massa acumulada (PMA), sólidos insolúveis em álcool (SIA), açúcares solúveis totais (AST), açúcares não redutores (ANR), açúcares redutores (AR), atividade de polifenoloxidase (PPO) e escurecimento enzimático e não enzimático foram analisadas. A PMA de tubérculos da cultivar Asterix a 6 e $8{ }^{\circ} \mathrm{C}$ e a da cultivar Cronos, armazenadas a $6{ }^{\circ} \mathrm{C}$ foram maiores. Os teores de SIA foram menores e os de AST, AR e ANR maiores nos tubérculos de ambas as cultivares armazenadas a $6^{\circ} \mathrm{C}$. A temperatura e o periodo de armazenamento não afetaram as cultivares Cronos e Asterix. O escurecimento foi maior nos palitos fritos das cultivares Asterix e Cronos armazenados a $6^{\circ} \mathrm{C}(4$ a 5 ) por 60 e 90 dias e a $8^{\circ} \mathrm{C}$ (2 a 3) por 180 dias, respectivamente. O periodo ideal de temperatura e armazenamento para as cultivares Asterix e Cronos é de $8{ }^{\circ} \mathrm{C}$ por, no máximo, 120 dias devido ao escurecimento não enzimático.

Palavras-chave: conservação, baixas temperaturas, batatas fritas, Solanum tuberosum L.

\section{INTRODUCTION}

Potato is the most important tuber worldwide (ZHANG et al., 2019), with 19,204,609 hectares of planted area and 386 million tons of annual production (AMJAD et al., 2017a). Potato is nutritionally benefic with components such as organic acids, fibers, minerals (phosphorus, magnesium and potassium), proteins and vitamins $B$ and C (HAASE, 2008).

The processed potatoes increase, mainly chips, is due to preparation and consumption convenience (CHEN et al., 2019). Potato tubers are planted in the summer and harvested in the fall (JANSKY \& FARJADO, 2014) and stored for use throughout the year in Brazil (BIANCHI et al., 2014). 
Technologies for potato tubers storage stabilize their quality during off-season (SOTOME et al., 2009).

Potato tubers, for industrial processing, must have high dry matter content, low sugar content and damage and disease free (SILVA et al., 2019). Low-temperature storage reduces losses from sprouting, wilting and diseases (XIAO et al., 2018). However, storage at temperatures lower than or equal to $6{ }^{\circ} \mathrm{C}$ induce amylases and phosphorylases synthesis (MALONE et al., 2006) reducing starch content by reducing sugars (glucose and fructose) and causing sweetening cold induced (XIAO et al., 2018; HAMEED et al., 2018).

Sweetened potato is generally rejected for frying (SOWOKINOS, 2001). In the United States, the largest potato chips consumer in the world, $15 \%$ of annual potato production is discarded due to sweetening (BHASKAR et al., 2010; CLASEN et al., 2016), leading to the search for tolerant cultivars (XIONG et al., 2002; HAMERNIK et al., 2009). The browning, caused by sweetening, varies between potato cultivars (SOWOKINOS, 2001) and can be reduced by controlling the storage temperature. Asterix and Cronos are cultivars used in industrial processing due to their short cultivation cycle, elongated tubers and light flesh (SILVA et al., 2018) and supposedly resistant to cold. The objective was to determine the ideal temperature and storage period for Asterix and Cronos cultivars for frying.

\section{MATERIALS AND METHODS}

\section{Experimental design and area characterization}

The experiment was in a completely randomized design, in subdivided plots, with the plots at temperatures 6 and $8{ }^{\circ} \mathrm{C}$ and the subplots being the storage periods of $30,60,90,120,150,180$ days with five replications, each experimental unit with five tubers to assess the PMA, AST, ANR, AR and PPO. Enzymatic and non-enzymatic browning was evaluated with five replications, each with 10 toothpicks. Tubers from the commercial cultivars, Asterix and Cronos, were produced in Araxá, Minas Gerais, Brazil (19³5' 36" S, 46 56' 27' O, 973 m altitude) over a period with an average temperature of $20{ }^{\circ} \mathrm{C}$ and precipitation of $134 \mathrm{~mm}$.

\section{Experimental procedure and analyses}

Potato tubers were harvested at 120-130 days after planting, cured for four days at $25^{\circ} \mathrm{C}$ and transported to the Post-harvest Physiology Laboratory at the Universidade Federal de Viçosa in Viçosa, Minas Gerais state, Brazil. These tubers were stored in a cold chamber (Gallant CMC4 Premium) inside plastic boxes. The soil residues were removed from the tubers without washing and they were stored at 6 or $8{ }^{\circ} \mathrm{C}$ and 85 and $95 \% \mathrm{RH}$, respectively. Accumulated mass loss (PMA), alcohol insoluble solids (SIA), total soluble sugars (AST), reducing (AR) and nonreducing (ANR) sugars, polyphenoloxidase activity (PPO) and enzymatic and non-enzymatic browning after $30,60,90,120,150$ and 180 days of cultivar tubers storage were evaluated.

\section{Accumulated mass loss (PMA)}

Five tubers from the commercial cultivars Asterix and Cronos stored at 6 and $8{ }^{\circ} \mathrm{C}$ were weighed monthly on an analytical balance and the accumulated mass losses calculated with the equation: $\mathrm{PMF}=(\mathrm{MI}-$ $\left.\mathrm{MF}^{*} 100\right) / \mathrm{MI}$, where: $\mathrm{PMF}=$ fresh weight loss per day $(\%) ; \mathrm{MF}=$ fresh weight of tuber at weighing day $(\mathrm{g})$; $\mathrm{MI}=$ initial fresh mass $(\mathrm{g})$.

Alcohol insoluble solids, total soluble sugars, reducing sugars and non-reducing sugars

Five grams of fresh pulp from five tubers were weighed, immersed in $80 \%$ ethanol at $65^{\circ} \mathrm{C}$, crushed and homogenized in polytron (Ultra turras IKA $^{\circledR}$ T25 digital) and centrifuged twice by 10 minutes at $2000 \mathrm{~g}$. Samples were filtered on filter paper, with each centrifugation, and the filtration volume combined into a single volume $(20 \mathrm{~mL})$ with ethanol in each beaker. The alcoholic extract was stored under refrigeration $\left(8^{\circ} \mathrm{C}\right)$ in sealed containers, to quantify the total and reducing soluble sugars.

\section{Alcohol insoluble solids}

The pellets from the step above were dried in a continuous flow oven at $65{ }^{\circ} \mathrm{C}$ for $24 \mathrm{~h}$ until dry mass stability, macerated in a crucible and weighed on an analytical balance (LA BONTE et al., 2000). The alcohol-insoluble solids content was determined by the residue from the total soluble sugars extraction from potato pellets.

\section{Total soluble sugars}

Total soluble sugars (AST) were quantified by the Phenol-sulfuric method (DUBOIS et al., 1956) with $250 \mu \mathrm{L}$ of the extracts from the pipetted potato tubers and with $250 \mu \mathrm{L}$ of $5 \%$ phenol solution added by sealed glass test tube with $10 \mathrm{~mL}$ capacity and vortexing, $1.25 \mathrm{~mL}$ of concentrated sulfuric acid added and the solution stirred again. The tubes were kept in a thermostatic bath $\left(30^{\circ} \mathrm{C}\right)$ for 20 minutes, stirred again, and kept at room temperature for 30 minutes. The readings were performed on a spectrophotometer 
(Genesys 10S UV-VIS) at $\lambda=490 \eta \mathrm{m}$, the standard curve made with $1 \%$ sucrose solution and the AST results expressed as a percentage.

\section{Reducing and non-reducing sugars}

The reducing sugars content was determined using the dinitrosalicylic acid (DNS) method (GONÇALVES et al., 2010). Five hundred microliters of alcoholic extract containing potato tubers fragments were pipetted through a glass test tube and $500 \mu \mathrm{L}$ of DNS added to each one and placed in a thermostatic bath at $100{ }^{\circ} \mathrm{C}$ for $5 \mathrm{~min}$. After cooling, $4 \mathrm{~mL}$ of distilled water was added to each tube for the final reaction mixture. The readings were performed on a spectrophotometer (Genesys 10S UVVIS) at $\lambda=540 \eta \mathrm{m}$ and the standard curve made with $0.2 \%$ fructose solution. The RA levels were expressed as a percentage. The non-reducing sugars (ANR) content was calculated by the difference between the total and reducing soluble sugars concentration and the results were expressed as percentage.

\section{Polyphenoloxidase (PPO) activity}

Five grams of fresh tuber pulp mass from each potato cultivar were immersed in $15 \mathrm{~mL}$ of extraction buffer $(0.1 \mathrm{M}$ potassium phosphate buffer, $\mathrm{pH}$ 6.5). This mixture was ground, filtered through gauze and centrifuged at $17,000 \mathrm{~g}$ for 30 minutes at $4{ }^{\circ} \mathrm{C}$. The PPO activity was determined by adding an enzymatic extract aliquot $(100 \mu \mathrm{L})$ to the reaction medium containing $1.5 \mathrm{ml}$ of $0.1 \mathrm{M}$ phosphate buffer ( $\mathrm{pH} 7.0), 0.5 \mathrm{ml}$ of catechol $(1.68 \%)$ and 0.9 $\mathrm{mL}$ of water. The PPO activity was determined in a spectrophotometer (UV-1601) with variation in absorbance for 3 minutes at $\lambda=420 \eta \mathrm{m}$ at $25{ }^{\circ} \mathrm{C}$. Results were expressed in EU min ${ }^{-1} \mathrm{mg}^{-1}$ protein (KAVRAYAN \& AYDEMIR, 2001).

The protein of the enzymatic extract was determined with the method of Bradford (1976) using BSA (bovine serum albumin) as standard. The protein content was determined using a mixture of $100 \mu \mathrm{L}$ of extract and $1 \mathrm{~mL}$ of Bradford's reagent and the protein quantified in a spectrophotometer (Genesys 10S UV-VIS) at $\lambda=595 \eta \mathrm{m}$ at $25^{\circ} \mathrm{C}$. The results were expressed in $\mathrm{mg}$ of protein in the enzyme extract.

\section{Enzymatic and non-enzymatic browning}

The potato tubers were peeled, cut longitudinally into $1 \mathrm{~cm}^{2}$ thick sticks with a manual cutter, fried in an electric fryer with a capacity of $3 \mathrm{~L}$ $\left(\right.$ Ford $\left.^{\mathbb{Q}}\right)$ and immersed in soy oil for three minutes at $180{ }^{\circ} \mathrm{C}$. The enzymatic browning of the sticks was visually evaluated before frying. The amount of oil used for frying was sufficient to minimize the temperature drop after immersing the potato sticks. The non-enzymatic browning of the fried sticks was visually determined, based on the panel equivalent to the 'United States Standards for Grades of Frozen French Fries Potatoes' (USDA, 1967), used by the potato processing industry.

\section{Data analysis}

The experimental design was completely randomized in subdivided plots with the plots at the temperatures 6 and $8{ }^{\circ} \mathrm{C}$ and the subplots being the storage periods of $30,60,90,120,150,180$ days with five replications, with five tubers per experimental unit.

The data were submitted to analysis of variance and regression using the SAEG 9.1 Statistical Analysis System (SAEG, 2007). The choice of the regression model was based on the significance of the regression coefficients using the $t$ test at a $5 \%$ probability level and on the determination coefficient $\left(\mathrm{R}^{2}=\mathrm{SQReg} / \mathrm{SQtrat}\right)$.

\section{RESULTS AND DISCUSSION}

The accumulated loss of fresh mass of the Asterix at 6 and $8{ }^{\circ} \mathrm{C}$ and the Cronos at $6{ }^{\circ} \mathrm{C}$ tubers was higher. The fresh weight loss increased with the storage time (Figure 1). The greater accumulated fresh mass losses of Cronos stored at $6{ }^{\circ} \mathrm{C}$ is explained by the lower relative humidity ( $10 \%$ lower) in the storage chamber and may be associated with a periderm thickness of this cultivar as an early one (HELTOFT et al., 2017). The similar accumulated loss between 6 and $8{ }^{\circ} \mathrm{C}$ for the late cultivar Asterix is due to its greater periderm thickness (HELTOFT et al., 2017) reducing the effect of low relative humidity at $6{ }^{\circ} \mathrm{C}$ (SILVA et al., 2019). The mass loss of tuber over the storage period is due to reserve consumption by respiration converting polysaccharides into sugars (SUTTLE et al., 2004; FINGER et al., 2018).

The alcohol insoluble solids (SIA) content was lower in the Asterix tubers after 180 and higher in the Cronos at 150 days of storage at $6{ }^{\circ} \mathrm{C}$, respectively (Figure 2). The lower SIA levels in the Asterix tubers at 180 days at $6{ }^{\circ} \mathrm{C}$ are due to the greater starch degradation by amylases, phosphorylases and glycolysis enzymes lability caused by cold (MALONE et al., 2006). The greater starch degradation in the Cronos tubers stored at $6{ }^{\circ} \mathrm{C}$ after 150 days and it's greater amylases and phosphorylases less degradation compared to Asterix (MALONE et al., 2006). Tubers with a higher starch content, such as those of Asterix, generally, have 

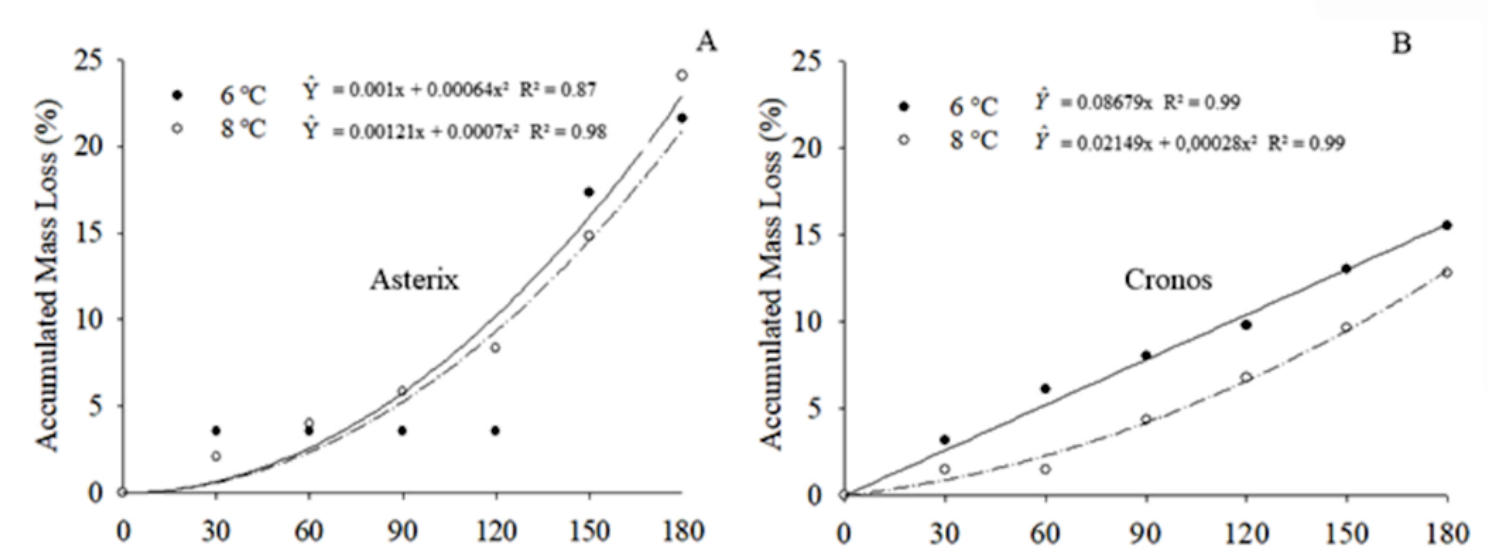

Figure 1 - Accumulated fresh mass losses (\%) of Asterix (A) and Cronos (B) potato cultivars stored at 6 or $8{ }^{\circ} \mathrm{C}$ to 180 days.

lower SIA levels at the end of the storage (AMJAD et al., 2017b). The enzymes activity that degrade starch into sucrose (ANR) is greater in tubers stored at 6 ${ }^{\circ} \mathrm{C}$ reducing the frying sticks quality during storage (SUN et al., 2018).

The levels of total soluble (AST), nonreducing (ANR) and reducing (AR) sugars were higher in the tubers, of both cultivars, stored at $6{ }^{\circ} \mathrm{C}$ with a peak at 30 days of storage and reduction in the other periods (Figure 3). The increase in the AST, ANR and RA content of the tubers at $6{ }^{\circ} \mathrm{C}$ up to 30 days of storage is due to the sucrose accumulation (SOWOKINOS et al., 2018), the reduction in the ANR and the increase in RA in the tubers of Asterix and Cronos stored at $6{ }^{\circ} \mathrm{C}$ after 30 days is due to the increase in invertase activity, cleaving, sucrose in fructose and glucose (RICHARDSON et al., 1990). The lower the storage temperature $\left(6^{\circ} \mathrm{C}\right)$, the greater the stress condition and the sugars accumulation that can function as cell cryoprotectants. The 30day storage period was sufficient to alter the sugar metabolism. The increase in the AST concentration

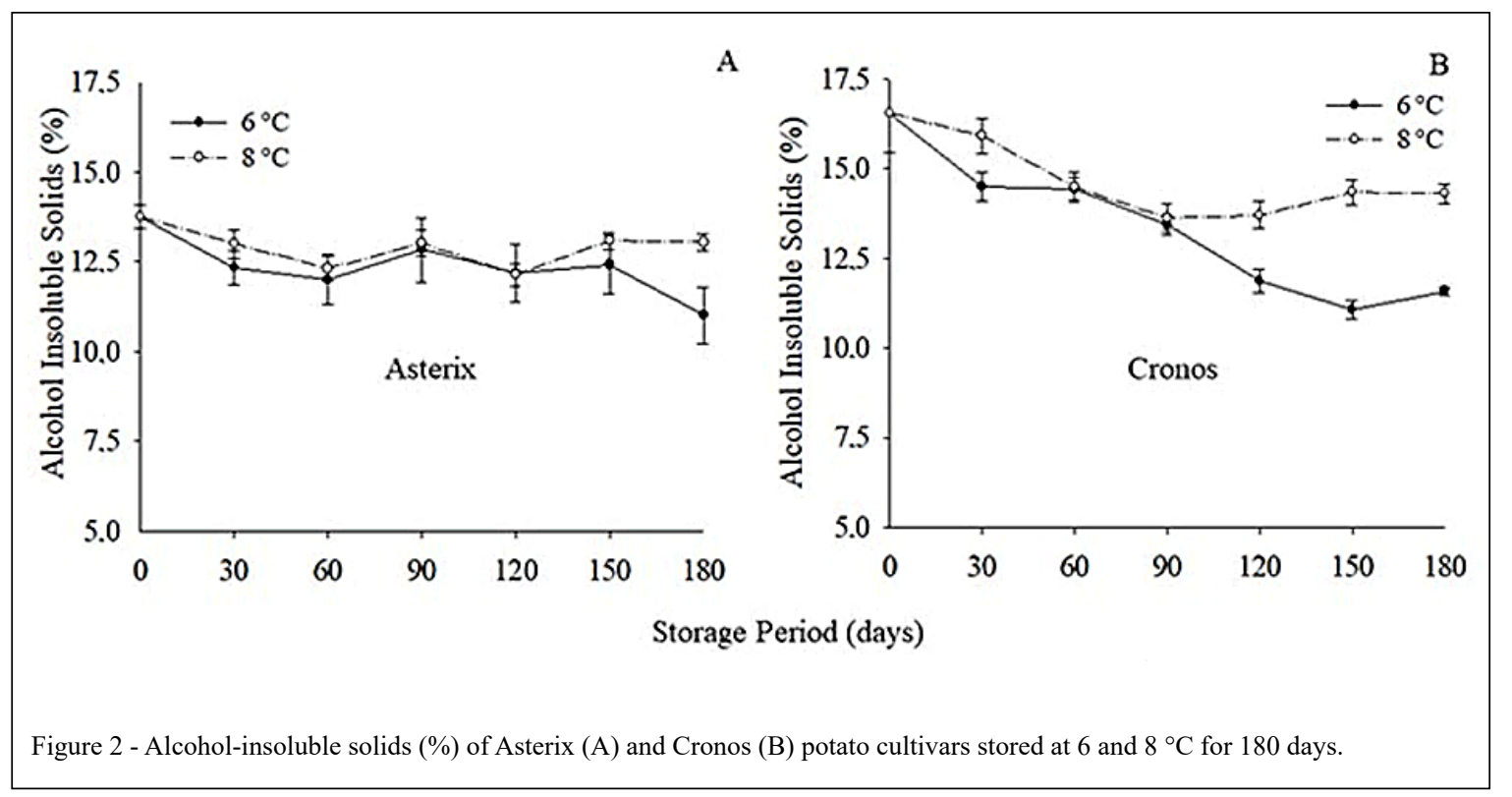

Ciência Rural, v.51, n.4, 2021. 


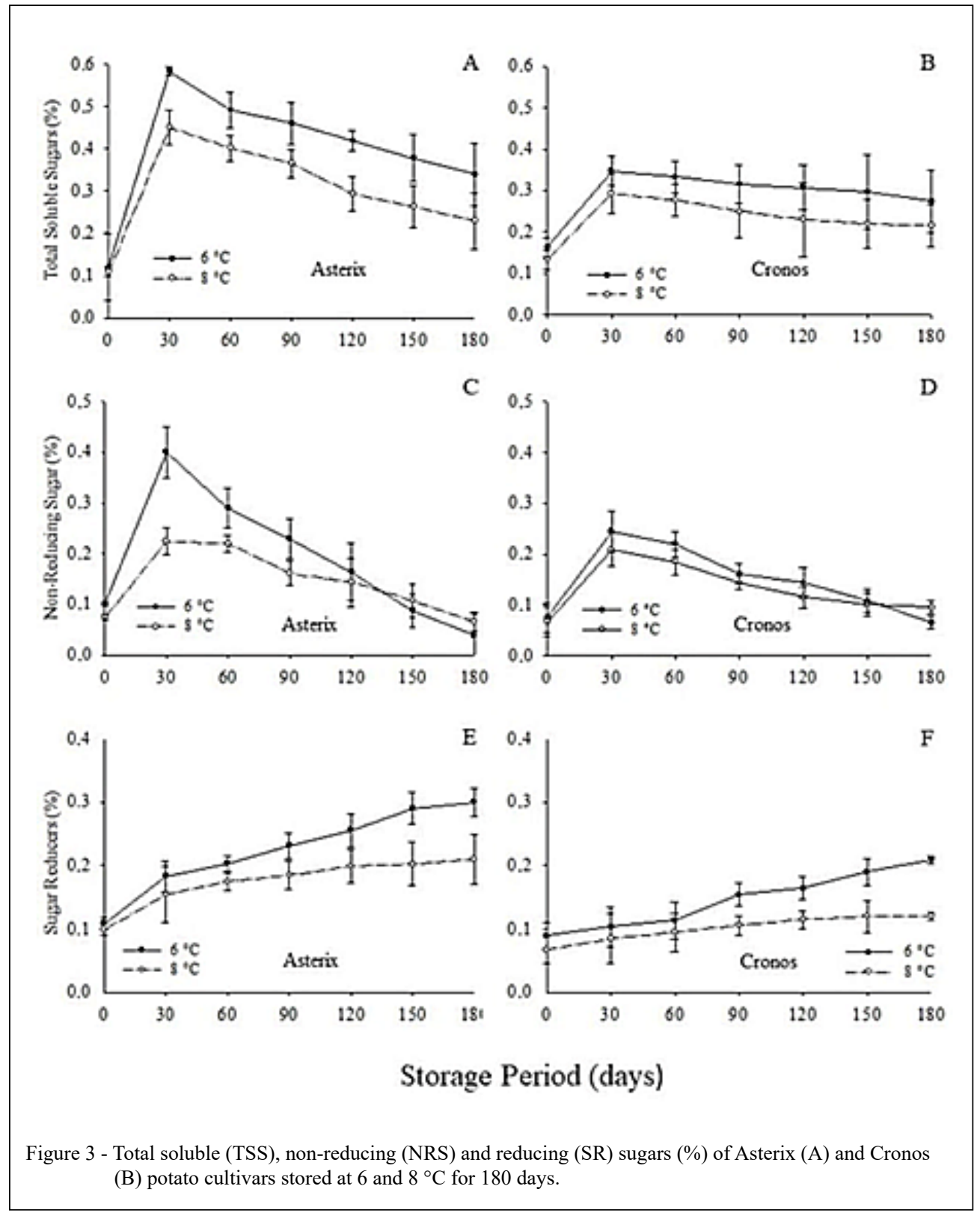

during storage occurs by breaking down the starch into ANR (sucrose), which is converted into AR (glucose and fructose) by invertase (RICHARDSON et al., 1990). The lower sugar accumulation in tubers stored at $8{ }^{\circ} \mathrm{C}$ is due to the lower invertase activity as reported for the potato cultivar Lady Roseta (AMJAD et al., 2017b; SUN et al., 2018).

The polyphenoloxidase (PPO) activity in the tubers of the Asterix and Cronos cultivars was similar between periods and storage temperatures (Figure 4). Enzymatic browning was not observed after cutting and processing potato tubers stored at 6 and $8{ }^{\circ} \mathrm{C}$ for up to 180 days (Figure 5). The similar PPO activity of potato cultivars at temperatures and storage periods is due to the short period between cutting and frying ( $<2$ minutes) (HOU et al., 2014), which prevents browning, due to the complete oxidation of the substrates by PPO, 10 minutes after the cut (SINGH \& WADHWA, 2017). Reducing the exposure time of enzymes to phenolic substrates and $\mathrm{O}_{2}$ decreases the chances of increasing PPO activity (FUGATE et al., 2016). Therefore, the 


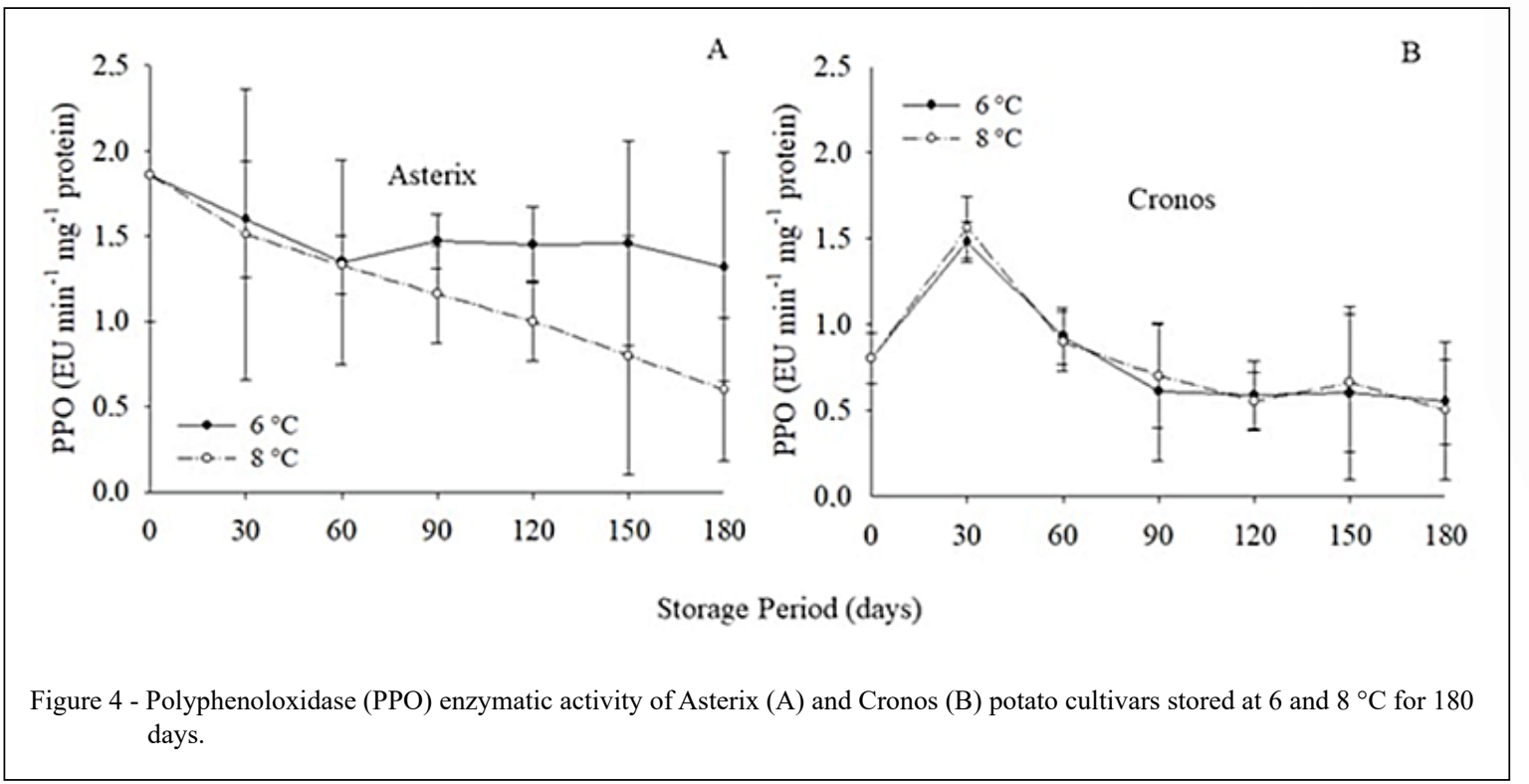

time between cutting and frying is essential to avoid enzymatic browning.

Non-enzymatic browning occurred in the Asterix tubers stored at $6{ }^{\circ} \mathrm{C}$ for 60 days and those of the Cronos for 90 days (Figure 6). Fried tuber sticks, from cultivars Asterix and Cronos, stored at $6{ }^{\circ} \mathrm{C}$, received grades 4 at 60 and 150 days and 5 at 180 days, respectively, and 2 and 3, from 30 days of storage, for both cultivars stored at $8{ }^{\circ} \mathrm{C}$ (Figure 6). The increase of the AR levels, induced by cold, explains the non-enzymatic fried sticks browning of the tubers stored at $6{ }^{\circ} \mathrm{C}$ (BALAGIANNIS et al., 2019). The greater activity of the amidolytic enzymes can explain the onset of non-enzymatic browning in the tubers of the cultivars Asterix and Cronos at 6 ${ }^{\circ} \mathrm{C}$ stored for 60 and 90 days, respectively (MALONE

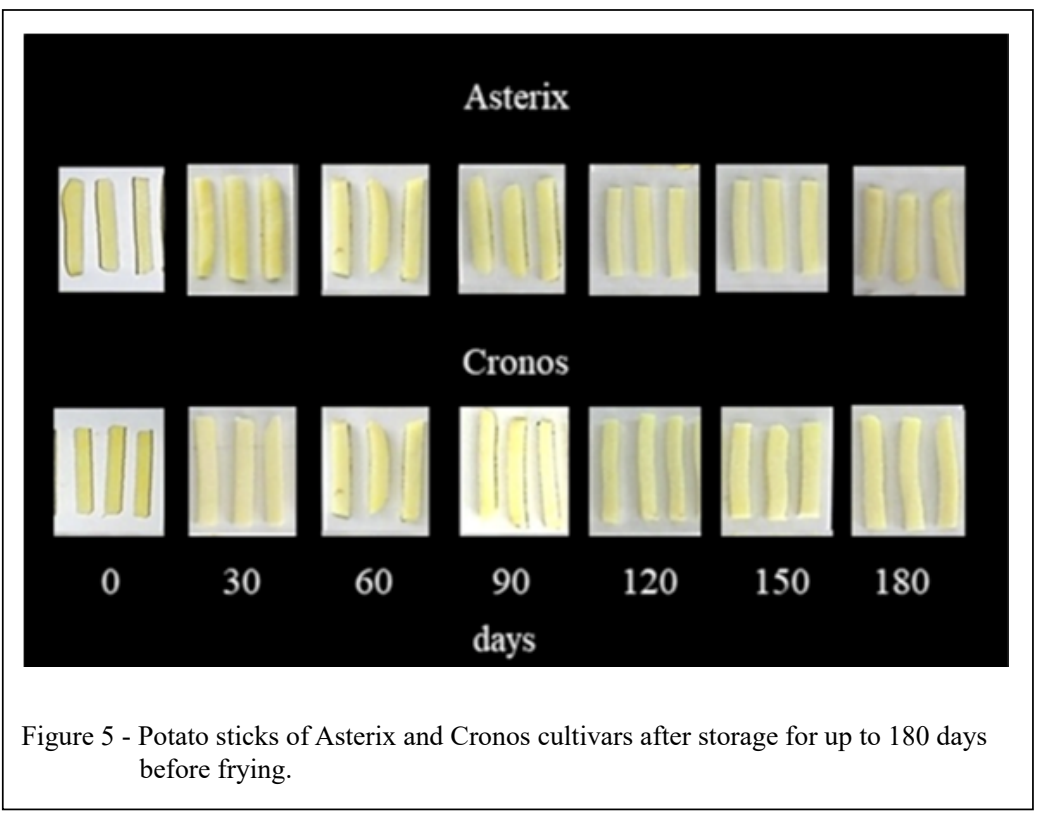

Ciência Rural, v.51, n.4, 2021. 


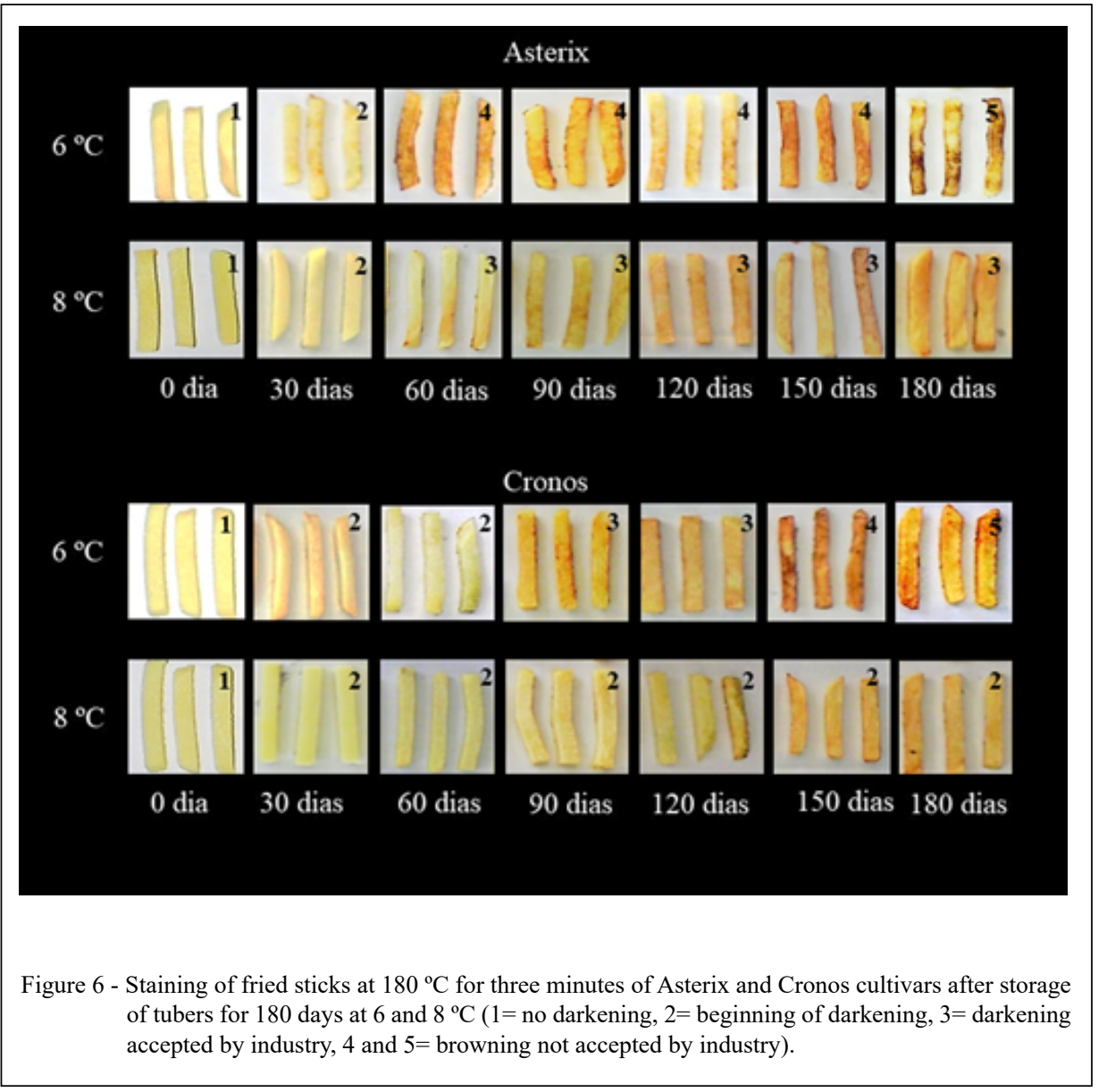

et al., 2006; AMJAD et al., 2017b). Part of the starch in the tubers is converted during storage into sucrose and; subsequently, into glucose and fructose, darkening tubers at $6{ }^{\circ} \mathrm{C}$ during (BUSSE et al., 2019). The grades 4 at 60 to 150 days and 5 at 180 days of the tubers of the cultivars Asterix and Cronos, respectively, stored at $6{ }^{\circ} \mathrm{C}$, are due to the RA greater accumulation in these periods (RICHARDSON et al., 1990).

\section{CONCLUSION}

Tubers of Asterix and Cronos cultivars should be stored at $8{ }^{\circ} \mathrm{C}$ for up to 120 days due to their non-enzymatic browning.

\section{ACKNOWLEDGEMENTS}

The authors thank FAPEMIG (Fundação de Amparo à Pesquisa de Minas Gerais), $\mathrm{CNPq}$ (Conselho Nacional de Desenvolvimento Científico e Tecnológico and was financed in part by the CAPES (Coordenação de Aperfeiçoamento de Pessoal de Nível Superior) (Processo número 88882.349320/2019-1), Brasil - Finance code 001 .

\section{DECLARATION OF CONFLICT OF INTERESTS}

The authors declare no conflict of interest. The founding sponsors had no role in the design of the study; in the collection, analyses, or interpretation of data; in the writing of the manuscript, and in the decision to publish the results.

\section{AUTHORS' CONTRIBUTIONS}

All authors contributed equally for the conception and writing of the manuscript. All authors critically revised the manuscript and approved the final version.

\section{REFERENCES}

AMJAD, A .et al. Screening potato cultivars for low sugar accumulation during storage at various storage. Pakistan Journal of Agricultural Sciences, v.54, n.2, p.343-347, 2017a. Available

Ciência Rural, v.51, n.4, 2021. 
from: <https://doi.org/10.21162/PAKJAS/17.5062>. Accessed: Feb. 20, 2019. doi: 10.21162/PAKJAS/17.5062.

AMJAD, A. et al. Assessing the processing quality of different potato cultivars during storage at various temperatures. Journal of the Chemical Society of Pakistan, v.38, n.5, p.1005-1013,2017b.

BALAGIANNIS, D. P. et al. Kinetic modeling of acrylamide formation during the finish-frying of French fries with variable maltose content. Food Chemistry, v.284, n.30, p.236-244, 2019. Available from: <https://doi.org/10.1016.j.foodch em.2019.07.075>. Accessed: Feb. 28, 2019. doi: 10.1016/j. foodchem.2019.01.075

BHASKAR, P. B. et al. Suppression of the vacuolar invertase gene prevents cold-induced sweetening in potato. Plant Physiology, v.154, n.2, p.939-948, 2010. Available from: <https://doi org/10.1104/pp.110.162545>. Accessed: Feb. 20, 2019. doi $10.1104 /$ pp. 110.162545

BIANCHI, G. et al. Non-destructive analysis to monitor potato quality during cold storage. Journal of Food Quality, v.37, n.1, p.9-17, 2014. Available from: <https://doi.org/10.1111/jfq.12068>. Accessed: Mar. 12, 2019. doi: 10.1111/jfq.12068.

BRADFORD, M. M. A rapid and sensitive method for the quantification of microgram quantities of protein utilizing the principle of protein-dye biding. Analytical Biochemistry, v.72, n.2, p.248-254, 1976. Available from: <https://doi.org/10. 1016/0003-2697(76)90527-3>. Accessed: Mar. 19, 2019. doi: $10.1016 / 0003-2697(76) 90527-3$.

BUSSE, J. S. et al. Transient heat stress during tuber development alters post-harvest carbohydrate composition and decreases processing quality of chipping potatoes. Journal of the Science of Food and Agriculture, v.99, n.1, p.2579-2588, 2019. Available from: <https://doi.org/ 10.1002/jsfa.9473>. Accessed: Mar. 19, 2019. doi: 10.1002/jsfa.9473.

CHEN, L. et al. Impact of amylose content on structural changes and oil absorption of fried maize starches. Food Chemistry, v.287, n.1, p.28-37, 2019. Available from: <https://doi. org./10.1016/j. foodchem.2019.02.083>. Accessed: Jan. 22, 2019. doi: 10.1016/j. foodchem.2019.02.083

CLASEN, B. M. et al. Improving cold storage and processing traits in potato through targeted gene knockout. Plant Biotechnology Journal, v.14, n.1, p.169-176, 2016. Available from: <https://doi. org/10.1111/pbi.12370>. Accessed: Dec. 15, 2019. doi: 10.1111/ pbi. 12370 .

DUBOIS, M. et al. Colorimetric method for determination of sugars and related substances. Analytical Chemistry, v.28, n.3, p.350-356, 1956. Available from: <https://doi.org/10.1021/ ac60111a017>. Accessed: Apr. 12, 2019. doi: 10.1021/ ac60111a017.

FINGER, F. L. et al. Action of essential oils on sprouting of non-dormant potato tubers. Brazilian Archives of Biology and Technology, v.61, n.1, p.1-10, 2018. Available from: $<$ https://doi. org/10.1590/1678-4324-2018180003>. Accessed: Jan. 10, 2019. doi: 10.1590/1678-4324-2018180003.

FUGATE, K. K. et al. Cold temperature delays wound healing in postharvest sugarbeet roots. Frontiers in Plant Science, v.7, n.1, p.1-14, 2016. Available from: <https://doi.org/10.3389/ fpls. 2016.00499>. Accessed: Apr. 2, 2019. doi: 10.3389/ fpls.2016.00499.

GONCCALVES, C. et al. Adaptation of dinitrosalicylic acid method to microtiter plates. Analytical Methods, v.2, n.12, p.2046-2048, 2010. Available from: <https: //doi.org/10.1039/C0AY00525H >. Accessed: Feb. 03, 2019. doi: 10.1039/ C0AY00525H

HAASE, N. U. Healthy aspects of potatoes as part of the human diet. Potato Research, v.51, n.4, p.239-258, 2008. Available from: $<$ https://doi.org/10.1007/s11540-008-9111-4>. Accessed: Feb. 10, 2019. doi: 10.1007/s11540-008-9111-4.

HAMEED, A. et al. Applications of new breeding technologies for potato improvement. Frontiers in Plant Science, v.9, n.1, p.e925, 2018. Available from: <https://doi.org./10.3389/fpls.2019.00925>. Accessed: Dec. 19, 2018. doi: 10.3389/fpls.2019.00925.

HAMERNIK, A. J. et al. Introgression of wild species germplasm with extreme resistance to cold sweetening into the cultivated potato. Crop Science, v.49, n.2, p.529-542, 2009. Available from: $<$ https://doi.org/ 10.2135/cropsci2008.04.0209>. Accessed: Mar. 8, 2019. doi: 10.2135/cropsci2008.04.0209.

HELTOFT, P. et al. Maturity indicators for prediction of potato (Solanum tuberosum L.) quality during storage. Postharvest Biology and Technology, v.129, n.1, p.97-106. 2017. Available from: $\quad<$ https://doi.org/10.1016/j.postharvbio.2017.03.011>. Accessed: Feb. 27, 2019. doi: 10.1016/j.postharvbio. 2017.03.011.

$\mathrm{HOU}, \mathrm{Z}$. et al. Effects of curing treatment on browning of fresh-cut potatoes. American Journal of Potato Research, v.91, n.6, p.665662, 2014. Available: <https://doi.org/10.1007/s12230-014-93966>. Accessed: May, 25, 2019. doi: 10.1007/s12230-014-9396-6.

JANSKY, S. H.; FAJARDO, D. A. Tuber starch amylose content is associated with cold-induced sweetening in potato. Food Science and Nutrition, v.2, n.6, p.628-633, 2014. Available from: $<$ https://doi.org./10.1002/fns3.137>. Accessed: Mar. 12, 2019. doi: $10.1002 /$ fns 3.137

KAVRAYAN, D.; AYDEMIR, T. Partial purification and characterization of polyphenoloxidase from peppermint (Mentha piperita). Food Chemistry, v.74, n.2, p.146-154, 2001. Available from: $\quad<$ https://doi.org.10.1016/S0308-8146(01)00106-6>. Accessed: May, 21, 2019. doi: 10.1016/S0308-8146(01)00106-6.

LA BONTE. et al. Carbohydrate-related changes in sweetpotato storage roots during development. Journal of the American Society for Horticultural Science, v.125, n.2, p.200-204, 2000. Available from: <https://doi.org./10.21273/JASHS.125.2.200>. Accessed: Mar. 27, 2019. doi: 10.21273/JASHS.125.2.200.

MALONE, J. G. et al. The response of carbohydrate metabolism in potato tubers to low temperature. Plant and Cell Physiology, v.47, n.9, p.1309-1322, 2006. Available from: <https://doi.org/10.1093/ pcp/pcj101>. Accessed: Feb. 12, 2019. doi: 10.1093/pcp/pcj101.

RICHARDSON, D. L. et al. Invertase activity and its relation to hexose accumulation of potato tubers. Journal of Experimental Botany, v.41, n.1, p.95-99, 1990. Available from: <https://doi.org/10.1093/ jbx/41.1.95>. Accessed: Mar. 20, 2019. doi: 10.1093/jbx/41.1.95.

SAEG - Sistema para análises estatísticas, versão 9.1: Fundação Arthur Bernardes - UFV -Viçosa. 2007. Available from: <http:// arquivo.ufv.br/saeg/>. Accessed: Dec. 10, 2018. 
SINGH, A.; WADHWA, N. Biochemical characterization and thermal inactivation of polyphenol oxidase from elephant foot yam (Amorphophallus paeoniifolius). Journal of Food Science and Technology, v.54, n.7, p.2085-2093. 2017. Available from: $<$ https://doi.org/10.1007/s13197-017-2647-z>. Accessed: Feb. 9, 2019. doi: $10.1007 / \mathrm{s} 13197-017-2647-z$.

SILVA, G. O. et al. Yield, frying quality, plant vigor, and maturity of potato clones. Horticultura Brasileira, v.37, n.1, p.95-100, 2019. Available from: <https://dx.doi.org/10.1590/s0102-053620190115>. Accessed: Jan. 20, 2019. doi: 10.1590/s0102-053620190115.

SILVA, G. O. et al. Selection of potato clones for tuber yield, vine maturity and frying quality. Horticultura Brasileira, v.36, n.2, p.276-281, 2018. Available from: <https://dx.doi.org/10.1590/ s0102-053620180222>. Accessed: May, 17, 2019. doi: 10.1590/ s0102-053620180222.

SOWOKINOS, J. R. Biochemical and molecular control of coldinduced sweetening in potatoes. American Journal of Potato Research, v.78, n.3, p.221-236, 2001. Available from: <https:// doi.org/10.1007/BF02883548>. Accessed: Apr. 28, 2019. doi: $10.1007 / \mathrm{BF} 02883548$

SOWOKINOS, J. R. et al. Coordinated regulation of cold induced sweetening in tetraploid potato families by isozymes of UDPglucose pyrophosphorylase and vacuolar acid invertase. American Journal of Potato Research, v.95, n.5, p.487-494, 2018. Available from: <https://doi.org/ 10.1007/s12230-018-9653-1>. Accessed: Jan. 27, 2019. doi: 10.1007/s12230-018-9653-1.

SOTOME, I. et al. Blanching of potato with superheated steam and hot water spray. LWT-Food Science and Technology, v.42, n.6, p.1035-1040, 2009. Available from: $<$ https://doi.org.10.1016/j. lwt.2009.02.001>. Accessed: Mar. 30, 2019. doi: 10.1016/j. lwt.2009.02.001
SUN, N. et al. Acrylamide formation in processed potatoes as affected by cultivar, nitrogen fertilization and storage time. American Journal of Potato Research, v.95, n.1, p.473-486, 2018. Available from: <https:// doi.org/10.1007/s1230-0789647-z>. Accessed: May, 16, 2019. doi: 10.1007/s1230-0789647-z.

SUTTLE, J. C. Physiological regulation of potato tuber dormancy. American Journal of Potato Research, v.81, n.4, p.253-264, 2004. Available from: <https://doi.org/ 10.1007/ BF02871767>. Accessed: May, 16, 2019. doi: 10.1007/ BF02871767.

USDA. United States Standards for Grades of Frozen FrenchFried Potatoes. USDA, Washington, 1967. 16p. Available from: $<$ https://www.ams.usda.gov/grades-standards/frozen-french-friedpotatoes-grades-and-standards $>$. Accessed: Feb. 25, 2019.

XIAO, G. et al. Genetic loci conferring reducing sugar accumulation and conversion of cold-stored potato tubers revealed by qtl analysis in a diploid population. Frontiers in Plant Science, v.9, n.1, p.e315, 2018. Available from: <https://doi.org/10.3389/ flps.2018.00315>. Accessed: Jan. 14, 2019. doi: 10.3389/ flps.2018.00315.

XIONG, X. et al. Effectiveness of selection for quality traits during the early stage in the potato breeding population. Plant Breeding, v.121, n.5, p.441-444, 2002. Available from: <https:// doi.org/10.1046/j.1439-0523. 2002.00699.x>. Accessed: Mar. 14, 2019. doi: 10.1046/j.1439-0523.2002.00699.x.

ZHANG, H. et al. SbRFP1 regulates cold-induced sweetening of potato tubers by inactivation of StBAM1. Plant Physiology and Biochemistry, v.136, n.1, p.215-221, 2019. Available from: $<$ https://doi.org/10.1016/j.plaphy.2019.01.019>. Accessed: Mar. 14, 2019. doi: 10.1016/j.plaphy.2019.01.019. 